\title{
JIN W KUNG FU - PODSTAWY FIZYCZNE
}

\section{Wstęp}

Kultura tradycyjnych chińskich sztuk walki charakterystycznych dla klasztoru Shaolin (buddyjskiej świątyni) jest równocześnie ekspansywna, filozoficzna oraz stanowi część światowego dziedzictwa kulturowego. W skład stylu walki wchodzi wiele form ręcznych i z bronia. Techniki te zawsze były przekazywane następnym pokoleniom jako usystematyzowane. Mimo to stajemy w obliczu ich fałszowania, co niszczy ich autentyczność. Jak zauważa przeor klasztoru Shaolin, Shi Yongxin, który opracował „Kompendium boksu klasztoru Shaolin”, problem potęguja zarówno programy treningowe szkół kung fu w Chinach, w których trenerzy w niewłaściwy sposób przekazują tajniki tej sztuki walki, jak i formuły rozgrywania zawodów sportowych. Widząc powage sytuacji, uznał, że na barkach świątyni leży uporządkowanie spraw szkoleniowych, a co za tym idzie - usystematyzowanie oraz standaryzacja technik i form.

W pierwszej kolejności skupiono się na próbie odtworzenia technik, które zostały zapomniane. Starano się dotrzeć zarówno do buddyjskich, jak i świeckich praktyków z okresu przed rewolucją kulturalną. W 2002 r. w obrębie klasztoru zorganizowano warsztaty Shaolin kung fu, na które zaproszono wspomnianych wyżej trenerów. Techniki kung fu zebrane w formy - następujące po sobie logicznie ułożone sekwencje ruchów - stanowia podstawę boksu shaolińskiego. Dobrze opanowane dają solidne przygotowanie do walki ${ }^{1}$.

W podejściu tym widoczny jest wpływ tzw. nurtu sportowego. Polega on na tym, że zawody w formach początkowo były rozgrywane w kilku konkurencjach, w których zawodnicy wykonywali tę samą formę. Jeśli jednak we wspomnianych zmianach zostanie zachowana tradycyjna metodyka nauczania, zawierająca m.in. aplikacje poszczególnych technik oraz walki zadaniowe i sparingowe, to oblicze tradycyjnego kung fu/wushu nie zostanie zatracone. Sztuka walki bowiem nie istnieje bez przygotowania ciała jako broni anatomicznej. Pytaniem jest, czy ten element, niejednokrotnie odstraszający od praktyki sztuk walki, zostanie ujęty w powyższych pracach.

1 Shi Yongxin, A Shaolin Monastery's Compedium of Pugilism - Datongbi Boxing, Henan 2007. 
Poprawne wykonywanie technik w chińskich sztukach walki jest opisywane często w kwiecisty, wręcz mityczny sposób. Jednak gdy odrzuci się epitety oraz mitologiczne rozważania, pozostaja fizjologiczne i fizyczne wręcz podstawy, które bardzo często są wykorzystywane przez wysokiej klasy zawodników boksu czy popularnej obecnie formuły MMA. Należy pamiętać, że efektywne techniki uderzeń muszą być wynikiem właściwego skoordynowania kilku czynników. Podstawową kwestią jest poprawne oddychanie zarówno podczas wykonywania ćwiczeń zadaniowych, jak i samej walki. Kontrola tego elementu pozwala na szybkie zmiany tempa ćwiczenia i walki, jak również wzmacnia energię wewnętrzną qi. Na wyższym poziomie zaawansowania dochodzi koncentracja oddechu w dantien ${ }^{2}$. Bardzo częstym błędem jest wstrzymywanie oddechu podczas ćwiczenia. Jedna z podstaw fizjologii jest zapewnienie dostatecznego natlenienia organizmu podczas wzmożonego wysiłku fizycznego.

Chińczycy przywiązują również dużą wagę do spojrzenia. Ma ono nie tylko podążać za uderzeniami, ale również zastraszyć przeciwnika (oczy nie mogą wyrażać nerwowości czy zakłopotania, co jest bardzo częste w przypadku początkujących adeptów).

Kolejnym aspektem jest praca nóg. Silne nogi są podstawą praktycznie każdego chińskiego stylu walki. Do wzmacniania tych kończyn służy m.in. poprawne wykonywanie pozycji ma bu (jeźdźca). Siła uderzenia jest generowana w dantien, natomiast cała technika zaczyna się od ruchu stopy. Następnie energia jest przekazywana poprzez nogi do talii, a z niej - do ramion i dłoni. Wielu początkujących zawodników wykorzystuje do uderzania same ramiona i ich mięśnie. Elastyczna talia spełnia funkcję osi, na której osadzone są koła (uderzające ramiona). Jeśli oś nie pracuje, cały mechanizm zawodzi.

Wynikiem takiej pracy ciała jest jin, który łączy omówione elementy w jedną spójną technikę. Jest on często określany jako uderzanie bezmięśniowe, które polega na generowaniu energii z rozluźnionego ciała. W tzw. zewnętrznym wushu tradycyjnym występuja dwa rodzaje jin: fa jin (wybuchowy jin), który jest związany z wyzwalaniem energii, oraz bua jin (neutralizujący jin), mający za zadanie zneutralizowanie energii ciosu zadanego przez przeciwnika ${ }^{3}$. Sifu Adam Hsu, uznany ekspert tradycyjnego kung fu, wyjaśnia, że słowo jin bywa zamiennie używane ze słowem $j i n g-\operatorname{moc}^{4}$. Jednocześnie tłumaczy, że jest to błędne, ponieważ moc nie pochodzi $z$ treningu kung fu. Według niego moc jest czymś naturalnym, z czym się rodzimy. Ponadto jest ona używana przez dłuższy czas, działa na większą powierzchnię. Biorąc pod uwagę właściwości destrukcyjne, moc jest słabsza od jin, którego cechą charakterystyczna jest penetracja celu ${ }^{5}$.

2 Dantien to środek ciężkości człowieka w kung fu.

L. Cahn, A 25-Point System for Rating Your Technique, „Black Belt Magazine”, August 1987.

http://www.adamhsu.com/adamhsu/sifu.html (dostęp: 13.12.2017).

5 http://www.adamhsu.com/articles/taiwanblog_FaJing1.html (dostęp: 13.12.2017). 


\section{Fizyczne podstawy kung fu/wushu ${ }^{6}$}

Fizyka to nauka, która nie pozostawia nic przypadkowi. Wszystko, co dzieje się w otoczeniu, podlega określonym prawom regulującym przemiany otaczającej nas materii. Prowadząc rozważania dotyczące sztuk walki, nie sposób pominąć zrozumienia tej dziedziny nauki, ponieważ ciosy i kopnięcia charakteryzują się wielkościami fizycznymi charakterystycznymi dla mechaniki. Jej składowymi są: kinematyka - opisująca ruch ciał oraz dynamika - opisująca siły działające na ciała oraz ich właściwości.

W rzeczywistości praca fizyka i osoby trenującej sprowadza się do tego samego, mianowicie do eksperymentowania. Zarówno w pierwszym, jak i w drugim przypadku polega ono na zaburzaniu pewnego układu fizycznego. W przypadku niepowodzenia należy zastanowić się, które prawo fizyki nie zostało spełnione lub które i dlaczego nie pozwala na osiąnięcie założonego celu. Zrozumienie wykonywanych ruchów, ich sensu i podstaw fizycznych obok wytrwałej praktyki jest jedną ze składowych prowadzacych do mistrzostwa.

Ważnym zagadnieniem przy rozpatrywaniu ruchu bądź dynamiki konkretnego ciała jest jego środek ciężkości. W sztukach czy sportach walki odpowiednia praca ze środkiem ciężkości stanowi podstawę zarówno skutecznej obrony, jak i ataków. W kung fu środek ciężkości człowieka nazywa się dantien. Teoria chińskich sztuk walki wyróżnia górne (tzw. trzecie oko, znajdujące się pomiędzy brwiami), środkowe (znajdujące się na splocie słonecznym) oraz dolne dantien (usytuowane trzy palce pod pępkiem). W przypadku zewnętrznych i wewnętrznych styli kung fu to ostatnie ma bardzo duże znaczenie. Jest to również centrum energetyczne człowieka. Mistrz stylu Xingyi, Wang Wenqing podczas swojej prezentacji na międzynarodowym kursie trenerskim zwracał uwagę na kontrolę dantien i jego poprawne umieszczenie w celu zapewnienia stabilności pozycji i siły uderzeń. Umieszczenie dantien pod pępkiem wynika z obliczeń środka ciężkości dla ciała człowieka. Jako dowód można przeprowadzić opisane poniżej obliczenia.

Środek ciężkości dla obiektu złożonego z $n$ figur płaskich wyraża się wzorem (1).

$$
S_{c}=\frac{\sum_{i=1}^{n} P_{i} \cdot r_{c i}}{\sum_{i=1}^{n} P_{i}}
$$

${ }_{6}$ Dziękuję panu dr. Piotrowi Arłukowiczowi, pracownikowi Zakładu Sztucznej Inteligencji Wydziału Matematyki, Fizyki i Informatyki Uniwersytetu Gdańskiego za cenne uwagi oraz ożywioną dyskusję dotyczącą fizycznych aspektów sztuk walki. 
gdzie:

$S_{c}$ - środek ciężkości,

$P$ - pole powierzchni $i$-tej figury,

$r_{c}$ - położenie środka geometrycznego $i$-tej figury,

$n$ - liczba figur.

Aby w prosty sposób wyliczyć położenie środka ciężkości człowieka, należy wprowadzić kilka uproszczeń do obliczanego modelu (rys. 1):

- wpisać sylwetkę człowieka w proste figury geometryczne,

- założyć symetrię i umieścić przygotowany model w początku układu współrzędnych.

Stosując powyższe podejście, wzór (1) przybiera postać (2).

$$
S_{c}=\frac{a \cdot b \cdot \frac{b}{2}+c \cdot d \cdot\left(b+\frac{d}{2}\right)+e \cdot f \cdot\left(b+d+\frac{e}{2}\right)+\pi \cdot g \cdot b \cdot(b+d+e+b)}{a \cdot b+c \cdot d+e \cdot f+\pi \cdot g \cdot b}
$$

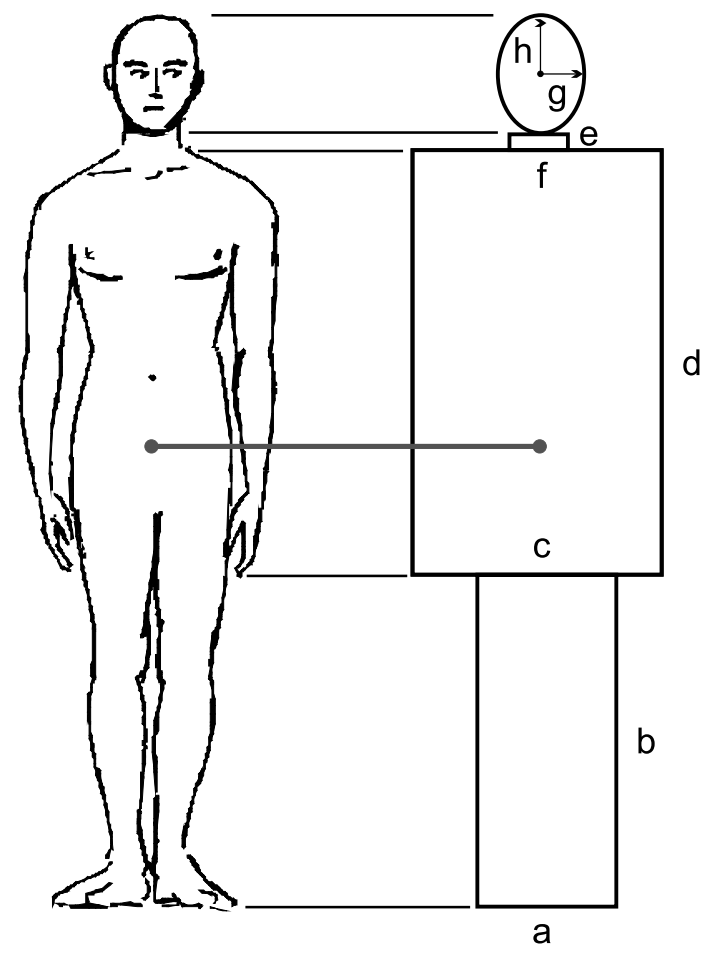

Rys. 1. Uproszczenie pozwalające obliczyć położenie środka ciężkości człowieka Źródło: Opracowanie własne. 
Kolejną wielkością fizyczną, której sens należy wyjaśnić, jest pęd wyrażony równaniem (3).

$$
\vec{p}=m \cdot \vec{v}
$$

gdzie:

$$
\begin{aligned}
& p \text { - pęd, } \\
& m \text { - masa, } \\
& v \text { - prędkość. }
\end{aligned}
$$

Ze wzoru (3) wynika, że nie ma znaczenia twardość i wielkość obiektu (tutaj np. rodzaj rękawicy), który nas uderza. Liczy się natomiast masa i prędkość. Prędkość nadaje pędowi kierunek. Uderzenia, które charakteryzują się dużą wartością pędu, są potężną bronią zdolną do wywołania wizualnego efektu. Jeśli przeciwnik usztywni się, takie uderzenie spowoduje jego przesunięcie, wytrącenie ze stanu równowagi lub nokaut. Wszystko zależy od umieszczenia celu względem środka ciężkości. Z kolei gdy jest rozluźniony, uderzenie spowoduje odrzucenie kończyn, prowadząc do otwarcia się oponenta na kontynuowanie ataku. Bardzo często powierzchnią uderzającą jest dłoń (w różnych ułożeniach) lub stopa. Średnia waga dłoni to około 0,5 kg. Taka masa nawet przy prędkości z zakresu 32-40 km/h (prędkość, z jaka uderzają zawodowi bokserzy) ma za mały pęd, aby przeciwnik odczuł takie uderzenie. Potrzeba tutaj dodatkowej masy, której powinno dostarczyć ciało w wyniku odpowiedniej pracy i zastosowania jin.

Ciało zaawansowanego praktyka powinno być rozluźnione po to, aby zwiększyć szybkość reakcji. Z jednej strony usztywnienie podczas walki, występujące bardzo często u osób początkujących, tylko pozornie daje poczucie bezpieczeństwa, a tak naprawdę jest to duże ułatwienie dla oponenta. Zatem im większe usztywnienie, tym mniejsza prędkość wyprowadzanych technik. Z drugiej strony usztywnienie ciała w odpowiednim momencie wykonywania techniki powoduje powstanie sztywnej drogi pomiędzy środkiem ciężkości a końcem uderzającej kończyny ${ }^{7}$. O ile klatka piersiowa jest sztywną częścią ciała, o tyle problem może stanowić brzuch. Dlatego też uderzeniom towarzyszy charakterystyczny szybki wydech, powodujący usztywnienie tej części ciała. Konsekwencją jest zwiększenie uderzającej masy, a co za tym idzie - pędu (nawet dwudziestokrotnie) i siły uderzenia ${ }^{8}$.

Początkowe rozluźnienie stanowi kluczowy element jin. Ponieważ dodatkowa masa jest konsekwencją przesunięcia środka ciężkości, wiele czasu poświęca

7 D. Bartel, D. Davy, T. Keaveny, Orthopaedic Biomechamics: Mechanics and Design in Musculoskeletal Systems, $6^{\text {th }}$ ed., Upper Saddle River 2006; O. Pinto Neto, M. Magini, Electromiographic and kinematic characteristics of Kung Fu Yau-Man palm strike, ,Journal of Electromyography and Kinesiology" 2008, no. 18, s. 1047-1052.

8 J. Thalken, Fight Like a Physicist, Wolfeboro 2015. 
się pracy z tą częścią podbrzusza. Dodatkowym elementem jest osadzenie dantien w momencie wykonywania uderzenia. Ma to na celu utrzymanie równowagi i stabilnej pozycji.

Wielkością fizyczną charakteryzująca jin jest energia kinetyczna, która została wyrażona za pomocą równania (4). Zawiera ona w sobie składową pędu, który jest kluczowy w niniejszych rozważaniach, co obrazuje równanie (5).

$$
E=\frac{1}{2} \cdot m \cdot v^{2}
$$

gdzie:

$E$ - energia kinetyczna,

$m$ - masa,

$v$ - prędkość.

$$
E=\frac{1}{2} \cdot p \cdot v
$$

gdzie:

$$
p \text { - pęd. }
$$

Uderzenia o wysokiej wartości energii powoduja uszkodzenie i spustoszenie w organizmie przeciwnika. Ich wielkość zależy od atakowanego miejsca. Jak wspomniano wcześniej, im większe rozluźnienie mięśni, tym większy pęd można uzyskać. Wykorzystanie punktów rotacji ciała oraz addytywności pędu prowadzi do uzyskania uderzeń o wysokiej energii kinetycznej. W uproszczeniu można przyjąć, że pęd całkowity ciosu w wushu składa się z czterech składowych: $p_{1}$ - pęd wyrzucanej pięty, $p_{2}$ - pęd biodra wyrzucającego ramię zadające cios, $p_{3}-$ pęd tułowia, $p_{4}$ - pęd ramienia zadającego uderzenie ${ }^{9}$. Reasumując, całkowita energia kinetyczna ciosu ma postać przedstawioną za pomocą równania (6).

$$
E=\frac{1}{2} \cdot \sum_{i=1}^{4} p_{i} \cdot v_{i}
$$

gdzie:

$p_{i}-$ pęd $i$-tej części ciała,

$v_{i}$ - prędkość $i$-tej części ciała.

Różnica pomiędzy ciosem charakteryzującym się dużą wartością pędu a tym o dużej wartości energii kinetycznej jest taka jak pomiędzy uderzeniem przez jadący

9 Masatoshi Nakayama, Dynamiczne karate, przeł. M. Matusiak, Bydgoszcz 2014. 
samochód a trafieniem przez wystrzelony pocisk. Różnica mas w przytoczonym przykładzie jest znaczna, ale to prędkość odpowiada za energię uderzenia. W walce prowadzonej w rękawicach bokserskich ciosy charakteryzują się dużą wartością pędu. Jin z kolei to uderzenia wykonywane dłonią w różnych ustawieniach, w których masa i powierzchnia części uderzającej jest mniejsza. Pozwala to na znaczący wzrost prędkości i wyprowadzenie ciosów o wysokiej energii.

We wszystkich omówionych dotychczas wielkościach fizycznych zawarta jest prędkość, którą wyraża wzór (7).

$$
v=\frac{s}{t}
$$

gdzie:

$v$ - prędkość,

$s-$ droga,

$t-$ czas.

Jak widać z powyższych rozważań, jest ona jednym z podstawowych elementów, które należy wziąć pod uwagę podczas treningu. Mnisi z klasztoru Shaolin podczas swoich pokazów przebijaja szybę za pomocą rzucanej igły. Wygląda to niewiarygodnie, aczkolwiek jest to efekt wypracowanego latami jin. Technika wyrzutu igły bazująca na podstawach fizycznych jest niemal identyczna z tą, jaka jest wymagana w przypadku uderzeń charakteryzujących się wysoką energią kinetyczna.

Wyprowadzanie ciosu prostego to bardzo dobry przykład ilustrujący złożoność wushu. Cała akcja zaczyna się od energicznego wyrzucenia pięty. Rozpoczyna to przekazywanie energii kinetycznej po spiralnym torze (rys. 2).

$\mathrm{Na}$ rys. 3 zaznaczono główne mięśnie, które są zaangażowane podczas wykonywania uderzenia. Zostały one podzielone na dwie grupy - mięśnie odpowiadające za dynamikę i ruch (D) oraz mięśnie statyczne, odpowiadające za utrzymanie pozycji $(\mathrm{S})^{10}$. Rolę poszczególnych mięśni opisano w tabeli 1.

10 N. Link, Lily Chou, The Anatomy of Martial Arts. An Illustrated Guide to the Muscles Used in Key Kicks, Strikes and Throws, Berkeley 2010. 


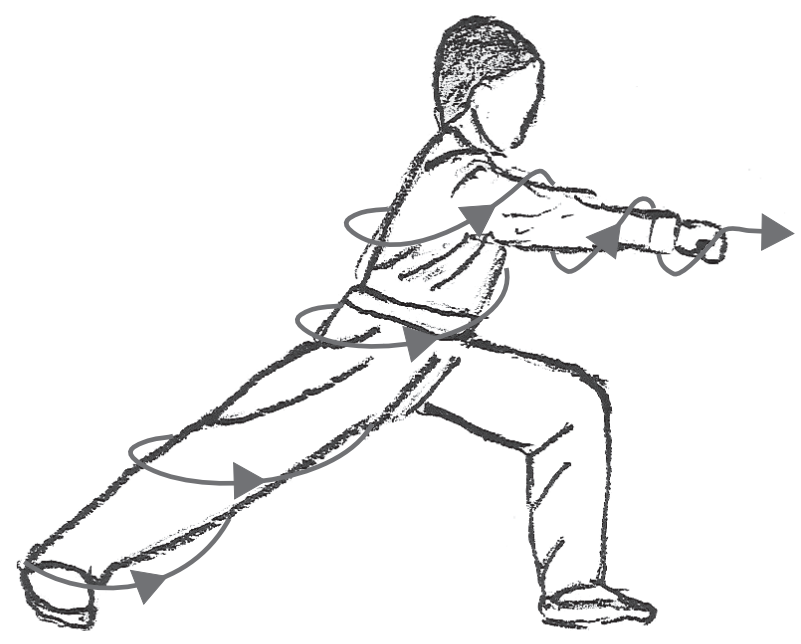

Rys. 2. Spiralny tor przekazywania energii kinetycznej podczas wyprowadzania ciosu prostego Źródło: Opracowanie własne.

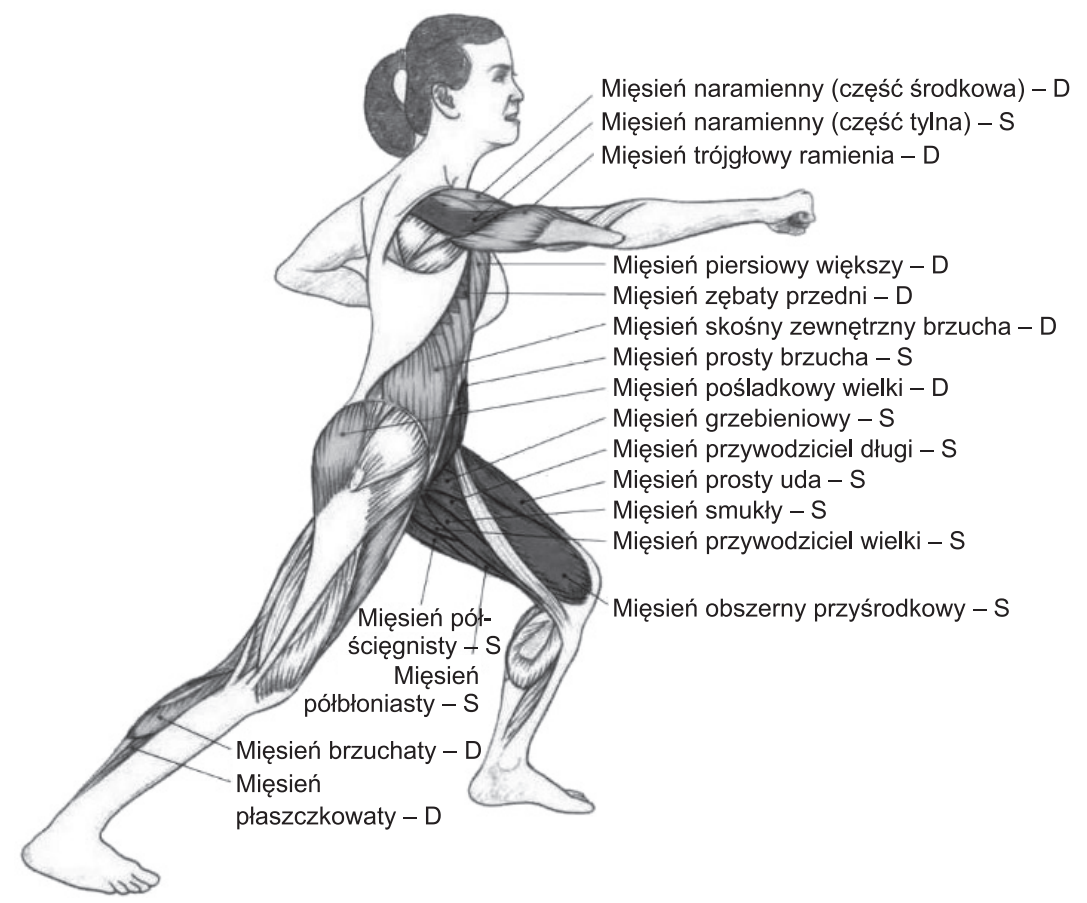

Rys. 3. Mięśnie zaangażowane w wyprowadzanie ciosu prostego

Źródło: Opracowanie na podstawie: N. Link, Lily Chou, The Anatomy of Martial Arts. An Illustrated Guide to the Muscles Used in Key Kicks, Strikes and Throws, Berkeley 2010. 
Tabela 1. Rola głównych mięśni zaangażowanych w wyprowadzanie ciosu prostego

\begin{tabular}{|c|c|}
\hline Rodzaj mięśnia & Rola mięśnia \\
\hline naramienny (część środkowa) & odwodzenie ramienia do poziomu \\
\hline naramienny (część tylna) & $\begin{array}{l}\text { przywodzenie ramienia, obrót na zewnątrz, podciaganie ramienia } \\
\text { do tyłu }\end{array}$ \\
\hline trójgłowy ramienia & odwodzenie, zginanie ku tyłowi \\
\hline piersiowy większy & $\begin{array}{l}\text { przywodzenie i obrót ramienia do wewnatrz, podciaganie } \\
\text { i opuszczanie ramienia, pomoc w oddychaniu (unosi mostek i górne } \\
\text { żebra) }\end{array}$ \\
\hline zębaty przedni & $\begin{array}{l}\text { część górna unosi łopatkę, część dolna działa antagonistycznie do } \\
\text { środkowej, część dolna pozwala unieść ramię, działa wspomagająco } \\
\text { przy wdechu }\end{array}$ \\
\hline skośny zewnętrzny brzucha & $\begin{array}{l}\text { zgina kręgosłup i skręca tułów, działa wspomagająco przy wydechu } \\
\text { (obniża klatkę piersiowa) }\end{array}$ \\
\hline prosty brzucha & zgina tułów, pracuje przy wydechu \\
\hline pośladkowy wielki & $\begin{array}{l}\text { najważniejszy mięsień przy stabilizacji wyprostowanej postawy, } \\
\text { rotacja uda na zewnątrz, przywodzenie i odwodzenie uda, działa } \\
\text { wspomagająco przy prostowaniu nogi w stawie kolanowym }\end{array}$ \\
\hline grzebieniowy & przywodzenie, zginanie i obrót uda na zewnątrz \\
\hline przywodziciel długi & przywodzenie, unoszenie i skręcanie uda na zewnątrz \\
\hline prosty uda & zginanie i odwodzenie stawu biodrowego, prostowanie kolana \\
\hline smukły & $\begin{array}{l}\text { przywodzenie, zginanie, obrót uda na zewnątrz, zginanie stawu } \\
\text { kolanowego i obrót na zewnątrz }\end{array}$ \\
\hline przywodziciel wielki & $\begin{array}{l}\text { przywodzenie i obrót uda na zewnątrz, zginanie i prostowanie stawu } \\
\text { biodrowego }\end{array}$ \\
\hline obszerny przyśrodkowy & prostowanie stawu kolanowego \\
\hline półcięgnisty & \multirow{2}{*}{$\begin{array}{l}\text { prostowanie i obrót do wewnątrz stawu biodrowego, zginanie } \\
\text { i obrót do wewnątrz stawu kolanowego }\end{array}$} \\
\hline półbłoniasty & \\
\hline brzuchaty & \multirow{2}{*}{$\begin{array}{l}\text { odpowiedzialne za zgięcie podeszwowe, inwersję stopy oraz } \\
\text { postawę w tyłopochyleniu }\end{array}$} \\
\hline płaszczkowaty & \\
\hline
\end{tabular}

Źródło: Opracowanie na podstawie: N. Link, Lily Chou, The Anatomy of Martial Arts...; E. Paulsen, J. Waschke, Sobotta - Atlas anatomii ç̨łowieka, tłum., oprac. i red. W. Woźniak, K.S. Jędrzejewski, Wrocław 2012.

\section{Ćwiczenia rozwijające jin}

Ćwiczenie zmiany czterech pozycji opisane poniżej pomaga wytrenować wspomnianą elastyczność talii, wzmacnia nogi i przygotowuje do zadawania uderzeń z wykorzystaniem jin. Te cztery pozycje to: ma bu (pozycja jeźdźca), gong bu (pozycja łuku lub wchodzącego pod górę), хи bu (pozycja kota) oraz xie bu (pozycja skrzyżna).

Sekwencję ich zmiany zaczyna się od pozycji ma bu, która jest podstawowa praktycznie we wszystkich stylach tradycyjnego wushu. W pozycji tej kolana znajdują się nad rozstawionymi stopami, natomiast uda powinny być równoległe do podłoża. 
Poprzez dynamiczne wyrzucenie jednej pięty do tyłu wykonuje się skręt ciała, przechodząc do pozycji gong bu, w której większość ciężaru ciała spoczywa na nodze wykrocznej. Zakroczna zaś musi być wyprostowana, a pośladki powinny znajdować się na wysokości stawu kolanowego ugiętej nogi wykrocznej. Poprawne wykonanie tego przejścia powoduje skręt bioder o $90^{\circ}$ oraz wyprostowanie nogi zakrocznej w stawie kolanowym. Następnie, skracając pozycję gong bu, przechodzi się do xu bu, również wykonując dynamiczną pracę rotacyjną talii. W pozycji kota $90 \%$ ciężaru ciała znajduje się na nodze zakrocznej, wykroczna zaś dotyka palcami podłoża. Jest ona odciążona, gotowa do szybkiej zmiany pozycji lub zadawania kopnięć. Ostatnią pozycją w sekwencji jest xie bu, w której cały ciężar ciała spoczywa na maksymalnie ugiętej nodze zakrocznej (rys. 4). Następnie przechodzi się do pozycji jeźdźca i rozpoczyna całą sekwencję w drugą stronę.

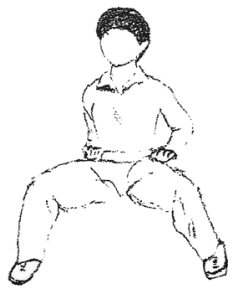

ma bu

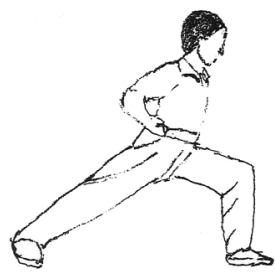

gong bu

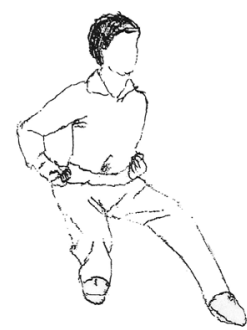

$x u b u$

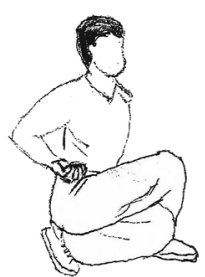

xie bu

Rys. 4. Ćwiczenie czterech pozycji wykorzystywane do wzmacniania nóg i praktyki jin

Źródło: Opracowanie na podstawie: Г. Музруков, Основы ущи, Издательский Аом „Городец”, Москва 2006.

Z poprawnej pracy nóg powinien wynikać ruch całego ciała. W tai-chi funkcjonuje powiedzenie: „Jeśli jedność się porusza - wszystko się porusza”. Oznacza to, że aby zmaksymalizować siłę uderzenia, należy używać ciała jako całości, nie zaś osobno jego części (rąk i nóg). Takie podejście wymusza perfekcyjną wręcz koordynację i ekonomikę wynikającą z podstaw fizyki.

Spośród wielu ręcznych układów formalnych, które wchodzą w skład shaolińskiego wushu, jeden zasługuje na szczególną uwagę. Tradycyjna forma datongbi oraz jej prostsza wersja tongbi (rys. 5) po raz pierwszy zostały opisane w kompendium boksu shaolińskiego przez buddyjskiego mnicha Fuju. Był on przeorem Shaolin za panowania dynastii Song (960-1279 r.). Od tego czasu niezliczona liczba luminarzy ze Świątyni Młodego Lasu praktykowała tę formę i próbowała ją udoskonalić. Doprowadziło to do jej obecnej postaci, która jest uważana za jedną z najlepszych, najbardziej kompaktowych i reprezentatywnych w stylu shaolińskim. Do jej mocnych stron zalicza się: zwięzłość połączoną z bojowościa, dokładnie usystematyzowane 
ruchy, prostotę połączoną z dynamiką, szybkość z agresywnościa, elastyczna, gibką obronę ze sprężystą obroną i adaptacyjność połączoną z praktycznością ${ }^{11}$.

Podstawą w liniowych technikach, na których ta forma bazuje, jest tytułowy jin i niezbędna do jego wygenerowania praca całego ciała. Formę tę wraz z wyjaśnieniem aplikacji bojowych poszczególnych ruchów przekazał mi były mnich z klasztoru Shaolin - Shi De Hong. Pomimo opuszczenia klasztornej braci wciąż pozostaje wyznawcą buddyzmu, która to religia jest nierozerwalnie związana ze sztukami walki ze Świątyni Młodego Lasu. Jest on nie tylko ekspertem tzw. zewnętrznego kung fu, ale słynie również z ogromnej wiedzy w zakresie qigongu ${ }^{12}$ i masażu leczniczego. W swojej praktyce łączy sztukę walki ze znajomością budowy ludzkiego ciała. Kung fu w jego wykonaniu to wręcz perfekcyjne wykorzystanie punktów witalnych. Shi De Hong jest uczniem dwóch wybitnych postaci shaolińskiego kung $\mathrm{fu}$ - mnicha Shi Su Xi, pełniącego w swoim czasie obowiązki przeora oraz Shi Su Yun, który za życia zasłużył sobie na umieszczenie jego podobizny na podwórcu drewnianych figur.

Ruchy występujące $\mathrm{w}$ formie Tongbi zaprezentowano na rys. $5^{13}$ :

1. Pozycja początkowa

2. Ruch poczatkowy

3. Wyrzuć pięść i osadź stopę

4. Pobij tygrysa

5. Wyrzuć pięść do przodu

6. Ułóż ramiona w linii

7. Skręcając się, zamknij żelazne wrota

8. Klaśnij prawą stopa

9. Poszukaj kwiatu, uderzając w przód

10. Schowaj kwiat pod pacha

11. Ukaż kwiat w pozycji $T$

12. Wyrzuć pięść, robiąc wypad w przód

13. Wyrzuć pięść w pozycji jeźdźca

14. Jastrząb skręca ciało

15. Wyrzuć pięść, robiąc wypad w przód

16. Dosiądź tygrysa

17. Uderz pięścią w ucho

18. Kontynuacja ruchu 17

11 Shi Yongxin, A Shaolin Monastery's Compedium of Pugilism - Datongbi Boxing, Henan People's Publishing House [b.m.] 2007.

12 Qigong - zestaw ćwiczeń zdrowotnych starożytnych Chin. Qigong składa się z dwóch słów: Qi, czyli życiowa energia, oraz Gong, czyli perfekcyjne opanowanie czegoś, np. perfekcyjne opanowanie sztuk walki to kung fu/gong fu.

13 Liu Haichao, Shaolin Gong-Fu. A Course in Traditional Forms, Henan Scientific and Technical Publishing House [b.m.] 1994. 


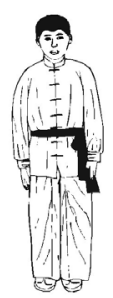

1

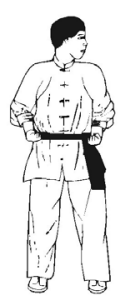

2

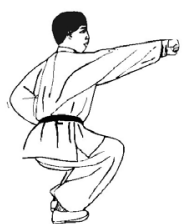

3

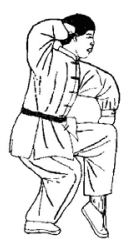

4

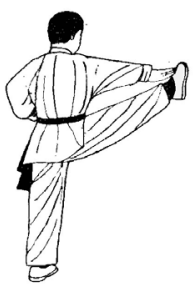

8

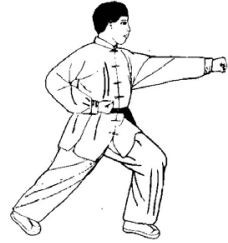

5

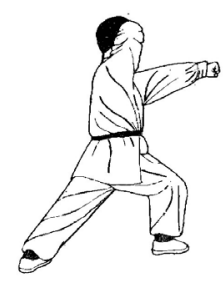

9

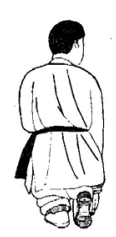

10

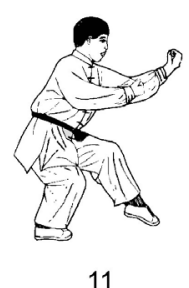

11

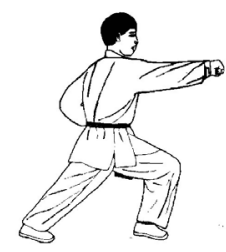

12

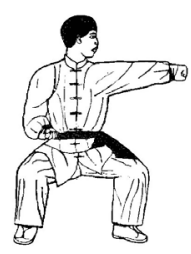

13

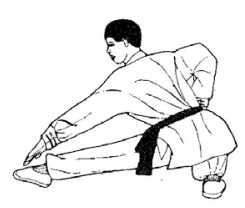

14

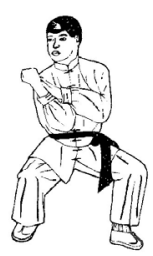

18

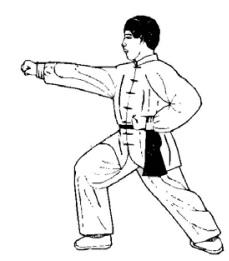

15

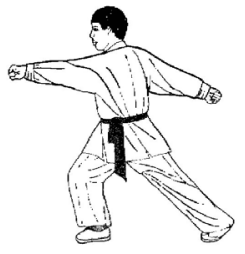

19

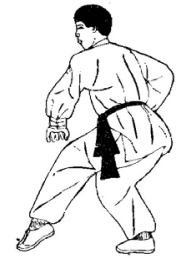

16

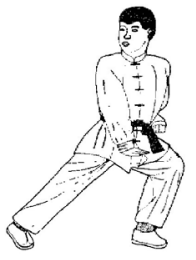

20

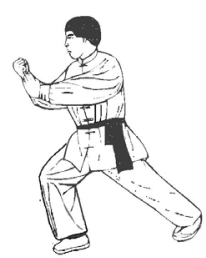

17

Rys. 5. Forma Tongbi Quan 


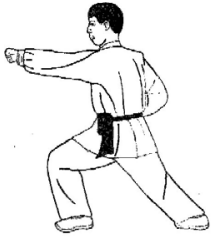

22

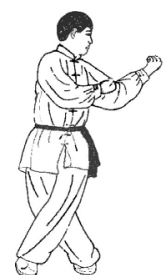

26

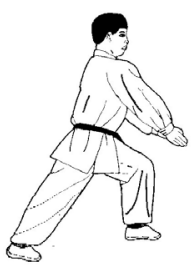

30

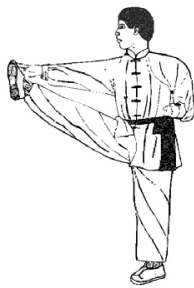

34

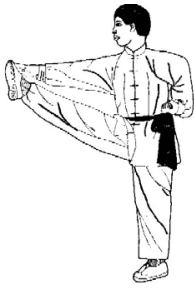

23

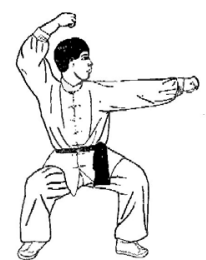

27

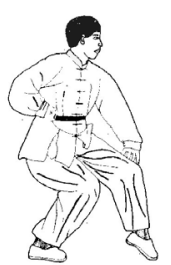

31

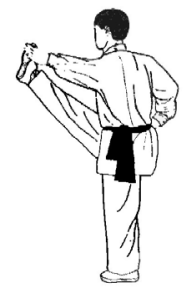

35

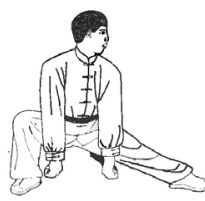

24

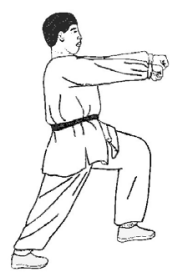

25

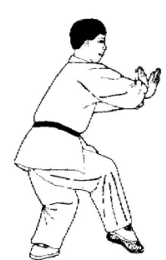

28

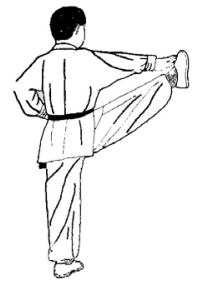

32

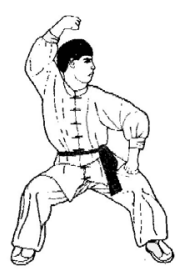

36

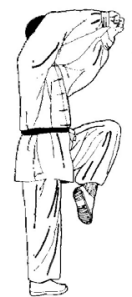

29

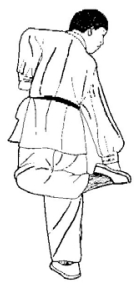

33

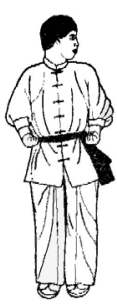

37

Rys. 5. cd.

Źródło: Liu Haichao, Shaolin Gong-Fu. A Course in Traditional Forms, Henan Scientific and Technical Publishing House [b.m.] 1994. 
19. Wyrzuć ramiona w linii

20. Przeprowadź kozę przez przejście

21. Klaśnij lewą stopa

22. Wyrzuć pięść, robiąc wypad w przód

23. Klaśnij prawą stopa

24. Wyrzuć pięści w dół w pozycji wiatru

25. Obróć obie pięści w górę

26. Uderz w twarz w pozycji krzyżowej

27. Zablokuj i zaatakuj w pozycji jeźdźca

28. Skrzyżuj ramiona w pozycji kota

29. Uderz w uszy obiema pięściami

30. Klaśnij w dłonie przed kolanem

31. Dosiądź tygrysa

32. Klaśnij prawą stopa

33. Smagające kopnięcie w tył

34. Klaśnij prawą stopa

35. Tornado

36. Bohater w pozycji jeźdźca

37. Pozycja zamykająca

\section{Część doświadczalna}

Podstawową wielkością fizyczną, którą dość łatwo zmierzyć, jest prędkość ciosu. Jak wykazano wcześniej, jest ona składową pozostałych wielkości fizycznych. Ponieważ jin, a w rzeczywistości jego jakość zależy od prędkości oraz od stażu treningowego (ze względu na trudności techniczne związane z jego opanowaniem), postanowiono zbadać zależność prędkości od tego właśnie czasu. Autorskie badania wykonano w klubie Shaolin Kung Fu - Sekcja Chińskich Sztuk Walki w Gdyni, bez podziału na kategorie wagowe ${ }^{14}$. Aby zmierzyć badaną wielkość, sfilmowano siedmioro ćwiczących, którzy trzykrotnie wykonywali cios prosty w postawie bokserskiej (rys. 6). Następnie poklatkowa analiza zarejestrowanego materiału pozwoliła na wyznaczenie średnich prędkości zgodnie ze wzorem (7). W tab. 2 zestawiono otrzymane wyniki.

Przeprowadzone badania potwierdziły, że jakość ciosów jest ściśle związana z długością praktyki. Regularny trening przez minimum 4 lata powoduje wzrost prędkości, która jest kluczową wielkością fizyczną w praktycznie wszystkich sztukach i sportach walki. Otrzymane wartości mogą odbiegać od danych opublikowanych

${ }^{14}$ W badaniu wykorzystano aparat Sony DSC-H9 oraz oprogramowanie do obróbki i nieliniowego montażu filmów - Edit Studio. 


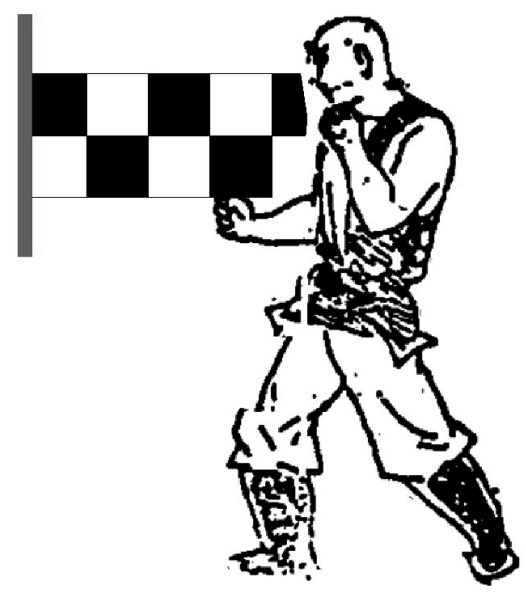

Rys. 6. Ilustracja ustawienia wykorzystanego podczas pomiaru prędkości ciosu Źródło: Opracowanie własne.

Tabela 2. Zestawienie otrzymanych średnich prędkości ciosu prostego

\begin{tabular}{|c|c|}
\hline Okres treningowy w latach & Średnia prędkość $\mathbf{( k m} / \mathbf{h})$ \\
\hline 1 & 10,0 \\
\hline 2 & 12,4 \\
\hline 3 & 11,7 \\
\hline 4 & 13,0 \\
\hline 5 & 16,2 \\
\hline 7 & 16,5 \\
\hline
\end{tabular}

Źródło: Opracowanie na podstawie badań własnych.

z tego względu, że zmierzona została prędkość ciosu od momentu wyprowadzenia do trafienia w tarczę. Dane publikowane natomiast często skupiają się na momencie, w którym prędkość jest największa.

\section{Podsumowanie}

Chińskie sztuki walki pomimo wejścia w XXI w. wciąż obracają się w kręgu mitów, tajemnic i niewiarygodnych na pierwszy rzut oka osiagnięć ludzkiego ciała. Nie ma w tym nic złego. Wszak barwne nazewnictwo technik czy legendy o początkach wushu, panteon bohaterów, do którego należy m.in. Sun Wukong (Małpi Król), czy wierszowane przekazy nauki poszczególnych technik i form stylowych stanowia nieodłączną część tradycji chińskiej, a co za tym idzie - także chuantong wushu. Myślę, że wykorzystanie chociażby podstawowej wiedzy z zakresu fizyki i biomechaniki 
ludzkiego ciała wraz ze wspomnianymi kwiecistymi opisami pozwoliłoby spojrzeć na sztuki walki bardziej realnie. Wraz z rozwojem wymienionych nauk ludzkie ciało staje się bowiem coraz bardziej znane. Dzięki temu również dobrze wyszkoleni trenerzy moga pomóc swoim podopiecznym przełamać etap stagnacji, co jest kluczowe w procesie szkoleniowym. Większa świadomość naukowa to również działanie na rzecz promocji wushu. Nie każdy przecież jest zainteresowany mitologią i tajemnicami starożytnych mistrzów. Połączenie jednego i drugiego (mitologii i nauki) powoduje, że każdy trenujący tradycyjne sztuki walki znajdzie w nich coś dla siebie. Szkolić można zarówno zawodnika, jak i osobę, która chce pokonać samego siebie (wygrać ze swoimi słabościami).

W niniejszym artykule zaprezentowano tylko jedno z wielu zagadnień tradycyjnego wushu. Niemniej jest to przykład, w jaki sposób można wytłumaczyć fakt, że pewne uderzenia, choć nie odrzucają przeciwnika, to powoduja jego niezdolność do walki. Nie każdy da się przekonać do wykorzystania „tajemniczej” energii qi. Racjonalne wytłumaczenie umożliwia zrozumienie tego, co dawno temu było niewytłumaczalne. Wszystko to dzięki zastosowaniu wzorów i metod eksperymentalnych, które w tamtym okresie nie były rozwinięte tak jak obecnie.

\section{SUMMARY}

\section{JIN IN KUNG FU - PHYSICAL BASICS}

Traditional wushu and the way of its teaching is full of mythological issues. Because of that the training process is not always clear enough. That is the bad marketing for Chinese martial arts these days. The proper systematization and standards of teaching are of key importance. Many schools concentrate on teaching forms (mainly for sport competition) without understanding of movements and their application. Traditional martial arts training consists of a few elements, namely: forms practice, application, qigong, hardening, and the most important sparrings. All these features combined with understanding of biomechanics and at least basics of physics give a comprehensive knowledge of what kung fu/wushu is. Nowadays, literature explanations should be passed to students together with scientific interpretation. For example, developing of high momentum punches resembles strikes of a thunder or adopting some stances is like rooting. The article touches the basics of physics of jin which is one of the most common elements in traditional wushu. All fundamental physical quantities such as: momentum, kinetic energy and velocity are explained. Additionally, the last one for punches was studied since it is a component of mentioned above. 